\title{
Janusz Mariański
}

\section{Wychowanie moralne w rodzinie}

Ius Matrimoniale 8 (14), 193-220

2003

Artykuł został zdigitalizowany i opracowany do udostępnienia w internecie przez Muzeum Historii Polski w ramach prac podejmowanych na rzecz zapewnienia otwartego, powszechnego i trwałego dostępu do polskiego dorobku naukowego i kulturalnego. Artykuł jest umieszczony w kolekcji cyfrowej bazhum.muzhp.pl, gromadzącej zawartość polskich czasopism humanistycznych i społecznych.

Tekst jest udostępniony do wykorzystania w ramach dozwolonego użytku. 
Ius Matrimoniale

8 (14) 2003

Ks. Janusz Mariański

\section{Wychowanie moralne w rodzinie}

\section{Wprowadzenie w problematykę}

W tradycyjnym społeczeństwie człowiek $z$ trudem mógł wyobrazić sobie małżeństwo bez rodziny. Dla niego małżeństwo i rodzina były niemal identyczne ${ }^{1}$. Rodzinę traktowano jako instytucję trwałą, o stabilnych więziach, opartą na małżeństwie między mężczyzną i kobietą, otwartą na przekazywanie życia, kształtującą osobowość człowieka od urodzenia aż do końca biologicznego życia. Małżeństwo było swoistym kontraktem, zawieranym najczęściej z inicjatywy rodziców lub krewnych, a nie samych narzeczonych. W sztywnych ramach instytucjonalnych węzeł małżeński znajdował potwierdzenie w wyraźnym podziale obowiązków między małżonkami, zgodnie z którym mężczyzna zarabiał na życie, a kobieta dbala o dom i dzieci².

„Patrząc historycznie na rodzinę jako instytucję społeczną, można zauważyć, że dawna rodzina miała więcej cech instytucji, a więc pełniła więcej funkcji, kierując się sformalizowanymi wzorcami zachowań i wzajemnych relacji między członkami (np. między małzonkami, pokoleniami itp.). Ewolucyjnie postępował proces $z$ jednej strony odformalizowania stosunków wewnętrznych oraz $-z$ drugiej strony - wyrównywania pozycji osób rodzinę tworzących w ramach pełnionych ról. Rodzina traciła stopniowo cechy grupy uniwersalnej, czyli takiej, która wszechstronnie zaspokaja potrzeby człowieka. Nie oznacza to jednak całkowitego zaniku jej instytucjonalnego charakteru, lecz jedynie zmianę zakresu i sposobów realizowania przez rodzinę jej funkcji”"

\footnotetext{
${ }^{1}$ Th. Herr. Patient Kirche - Was ist mit der Kirche los? Eine sozialwissenschaftliche Untersuchung. Paderborn 2001 s. 22.

${ }^{2}$ A. Giddens. Nowoczesność i tożsamość. Ja i społeczeństwo w epoce późnej nowoczesności. Tl. A. Szulżycka. Warszawa 2001 s. 124.

${ }^{3}$ M. Łączkowska. Wybrane zagadnienia z socjologii rodziny. W: Studium Rodziny (praca zbiorowa). Red. T. Rzepecki. Poznań 1999 s. 144.
} 
Współcześnie rodzina staje się raczej „wspólnotą emocjonalną”, traci cechy trwałej instytucji. Zmiana przebiega od stosunków bardziej rzeczowych dawniej, do stosunków osobowych i opartych na więziach uczuciowych - obecnie. Zmieniają się oczekiwania co do jakości życia rodzinnego. „Dawniej kładziono większy nacisk na instytucjonalny aspekt rodziny. Żywiono przekonanie, że rodzina jest przede wszystkim instytucją powolaną do wykonywania funkcji prokreacyjnej oraz opieki nad dziećmi i ich wychowywania. Była też traktowana jako instytucja organizująca i zapewniająca materialne warunki życia jej członkom. Obecnie toruje sobie drogę przekonanie, że życie małżeńskie ma wtedy jedynie sens, jeśli daje pełną satysfakcję współmałżonkom"4. Preferowaniu zaspokajania potrzeb emocjonalnych w rodzinie towarzyszy dynamiczny wzrost różnorodnych form wspólnotowego współżycia pozamałżeńskiego ${ }^{5}$.

Współcześnie traktuje się małżeństwo dość często jako decyzję na określony czas, „na próbę”, zawierane do końca życia („aż do śmierci") wydaje się zbyt ryzykowną decyzją. Wielu mlodych ludzi odkłada na później zawarcie małżeństwa, albo waha się je zawierać ze względu na trudności ekonomiczne. Współżycie seksualne przedmałżeńskie jest traktowane jako oczywistość. Ślub kościelny staje się często społecznym wydarzeniem, ale bez mocy wiążącej „na stałe”. Rozwody są przez wielu traktowane jako fakt godny pożałowania, ale społecznie tolerowany. Rodzina - nawet przy najwyższych wysiłkach - jest zdolna wypełniać tylko częściowo swój mandat wychowawczy. Zrodzenie i wychowanie dzieci traktuje się niekiedy jako ciężar gospodarczy dla rodziny, przeciwstawia się prawa dzieci prawom rodziców. Niektóre z funkcji rodziny (prokreacyjno-seksualna, produkcyjna, opiekuńczo-usługowa, socjalizacyjna, emocjonalno-ekspresyjna, zabezpieczająca $)^{6}$, tracą na znaczeniu lub zmieniają nieco swój profil. Coraz wyraźniej zaznacza się prymat uczuć i autonomizacja aktorów społecznych w rodzinie. Współcześnie zostały podważone podstawy rodziny jako instytucji, propaguje się nowe, konkurencyjne modele życia małżeń-

\footnotetext{
${ }^{4}$ Z. Tyszka. Rodzina w świecie współczesnym - jej znaczenie dla jednostki i społeczeństwa. W: Pedagogika społeczna. Człowiek w zmieniającym się świecie. Red. T. Pilch, I. Leparczyk. Warszawa 1995 s. 146.

${ }^{5}$ A. Keppler-Seel, H. Knoblauch. Familie als kommunikatives Netzwerk. W: Moral im Alltag. Sinnvermittlung und moralische Kommunikation in intermediären Institutionen. Hrsg, von Th. Luckmann. Gütersloh 1998 s. 63.

${ }^{\circ} \mathrm{M}$. Lączkowska, jw. s. 144.
} 
skiego. Te wszystkie cechy współczesnych rodzin pozwalają szkicować ewolucję od nowoczesnej do ponowoczesnej rodziny?.

W procesie wychowania rodzice przekazują swoim dzieciom różnorodne wartości i cele o charakterze moralnym i pozamoralnym. Jednym $\mathrm{z}$ nich przypisują priorytetowe znaczenie, innym zaś drugorzędne. Rodzina jest podstawową i niezastąpioną wspólnotą wychowawczą, środowiskiem stwarzającym najlepsze warunki do przekazywania wartości pomagających jednostce w ukształtowaniu własnej tożsamości, wartości istotnych dla rozwoju całego spoleczeństwa. Pośredniczy pomiędzy jednostką a społeczeństwem. Rodzina stanowi cel i ważne miejsce w życiu ludzi współczesnych, jednak stabilność i ciąglość rodziny zeszły w rzeczywistości na drugi plan, a nawet mogą stanowić przeszkodę $\mathrm{w}$ realizacji ekspresyjnych funkcji niektórych członków rodziny. Rodziny tracą charakter wspólnot produkcyjno-konsumpcyjnych, stając się wspólnotami opartymi na uczuciach, z natury mniej stabilnych w porównaniu $\mathrm{z}$ więziami ekonomicznymi ${ }^{8}$.

„Niektóre z tych tradycyjnych aspektów małżeństwa utrzymują się nadal, szczególnie w pewnych grupach socjoekonomicznych. Jednak ogólną tendencją, zapoczątkowaną przez pojawienie się miłości romantycznej jako głównego motywu zawierania związków małżeńskich, jest eliminacja tych istniejących uprzednio obowiązków. Małżeństwo staje się w coraz wyższym stopniu związkiem tworzonym i podtrzymywanym o tyle, o ile bliski kontakt $z$ drugą osobą jest źródłem satysfakcji emocjonalnej. Jak się też okazuje, jego inne aspekty, nawet pozornie tak fundamentalne jak posiadanie dzieci, nie tylko nie cementują związku, ale mogą przyczyniać się do jego postępującego rozkładu".

Zmieniają się oczekiwania normatywne wobec rodziców, słabnie dominacja jednego z partnerów w małżeństwie. Wszyscy członkowie rodziny biorą udział w podejmowaniu decyzji odnoszących się do ważnych problemów związanych $\mathrm{z}$ rodziną. Dzieci nie tyle są traktowane jako własność rodziców, dar Boży czy zadanie narodowe, wreszcie obiekt wychowania, lecz jako indywiduum (osoba), z własną drogą ży-

\footnotetext{
${ }^{7}$ F. de Singly. Die Familie der Moderne. Eine soziologische Einführung. Konstanz 1994 s. 157.

${ }^{8}$ W. Kwaśniewicz. Kilka refleksji o przemianach moralności w okresie transformacji ustrojowej. W: Moralność Polaków. Etos i etnos. Dylematy wspólczesności. Red. B. Gołębiowski. Łomża 2001 s. 69.

${ }^{9}$ A. Giddens, jw. s. 124-125.
} 
ciową i projektem życia. „Badania wykazują, że obecnie rodzice nie mogą przewidzieć, czego dzieci będą potrzebować w przyszłości jako ludzie dorośli. Dzieci są bardzo wcześnie zapraszane do uczestnictwa w podejmowaniu decyzji dotyczących ich przyszłego życia. Nie tylko pozwala im się na ich podejmowanie, ale wręcz obliguje się je do tego. Rodzice zmierzają do zmniejszenia znaczenia własnych interwencji, przychylając się do zachęcania dziecka do częstszego okazywania wlasnych postanowień. Zwykle stosują się do tego w sprawach dotyczących religii" ${ }^{\prime \prime}$.

W rodzinie współczesnej obowiązuje egalitaryzm w stosunkach między malżonkami oraz między rodzicami i dziećmi. Jednostka i jej potrzeby stają się naczelną zasadą $\mathrm{w}$ rodzinie ${ }^{11}$. Wzrasta potrzeba doznania opieki i oparcia emocjonalnego, zostaje zredukowana potrzeba uległości i podporządkowania. Złożone procesy socjalizacyjno-wychowawcze $w$ rodzinie są realizowane przez interakcje oparte na komunikowaniu spolecznym. W wyraźnym odwrocie jest stosowanie kar cielesnych. W wychowaniu częściej preferuje się „miękkie" metody i techniki oddziaływania na dzieci, odchodzi się od autorytarnego stylu wychowania do partnerskiego, uwzględniającego swobodny rozwój dziecka, tolerancję i dialog. Unika się ekstremalnych technik i sposobów oddziaływania wychowawczego. Zarówno w mieście jak i na wsi pogłębiają się procesy demokratyzacji życia codziennego.

Zmiany w wartościach dokonują się w jeszcze do niedawna „zamkniętych" środowiskach wiejskich. Tradycyjny, względnie spójny system wartości chłopskich należy do przeszłości. Część dawnych wartości uznawanych przez mieszkańców wsi zanikła bezpowrotnie, inne uległy osłabieniu, a pozostałe przeszły swego rodzaju ewolucję. Kierunek przemian można określić jako upodabnianie się wsi pod pewnymi względami do reszty społeczeństwa. Transformacja chłopskiej aksjologii dotyczy nie tylko ziemi, gospodarstwa i pracy, ale i rodziny, religii, świadomości narodowej itp. ${ }^{12}$. Dawniej wykształcenie nie było traktowane w środowisku wiejskim jako wartość autoteliczna. Obecnie rodzice traktują wykształcenie swoich dzieci jako podstawę do zajęcia

\footnotetext{
${ }^{10}$ H. -G. Ziebertz. Religijność i wychowanie w świecie pluralistycznym. Kraków 2001 s. 28.

"U. Beck. Die Jugend von heute! Wider das Lamento über den Werteverfall. „Aviso. Zeitschrift für Wissenschaft und Kunst in Bayern" 1998 nr 2 s. 11-14.

${ }^{12}$ J. Styk. Chlopski świat wartości. Studium socjologiczne. Wlocławek 1993 s. 117.
} 
odpowiedniego miejsca w strukturze społecznej. Często dotyczy to wykształcenia średniego, rzadziej wyższego ${ }^{13}$.

W warunkach szybkich zmian społecznych pojawia się zasadnicze pytanie, czy mamy jeszcze do czynienia z kontynuacją, czy też może $\mathrm{z}$ przełomem $\mathrm{w}$ przekazie wartości moralnych $\mathrm{w}$ rodzinie. Współczesne przemiany społeczne stwarzają i pociągają za sobą zakłócenia w funkcjonowaniu rodziny, niekiedy nawet zagrożenia dla podstaw jej egzystencji. Powszechnie mówi się o kryzysie rodziny, o daleko idących metamorfozach, o przewadze tendencji dezintegracyjnych nad integracyjnymi. W warunkach rozwoju alternatywnych form życia małzeńskiego $\mathrm{w}$ społeczeństwach pluralistycznych rodzina staje się jedną $\mathrm{z}$ wielu opcji. Zmiany dokonują się w strukturze i funkcjach rodziny. Małżeństwo i rodzina nie są traktowane wyłącznie w kategoriach obowiązku i zadania, lecz także - a może przede wszystkim - jako czynnik własnego rozwoju warunkującego poczucie bezpieczeństwa i szczęścia. Zmienia się przekaz wartości moralnych w rodzinie.

Wielu młodych ludzi nie chce poświęcać swego osobistego szczęścia dla nieudanej rodziny, ani własnego rozwoju dla dobra swoich dzieci, wielu nie jest w stanie naśladować i przyjąć wzorów kulturowych pokolenia rodziców. Jednostki uzyskują znaczną swobodę niezależnego działania na własną odpowiedzialność. Nie wszystkie funkcje wychowawcze wobec młodego pokolenia są realizowane w rodzinie. Zmienia się także pojęcie rodziny jako składnika osobistego szczęścia. „Rodzina przestała być postrzegana jako naturalny i konieczny składnik własnej biografii, a przy tym jako oczywisty segment świata społecznego. Wejście w życie rodzinne staje się w świadomości młodzieży po prostu tylko jedną z możliwych decyzji, wynikiem indywidualnego wyboru. Wybór ten może stanowić konsekwencję poczucia obowiązku moralnego, może jednak również wyplywać z poszukiwania silnych doznań i związków emocjonalnych"14.

W niniejszym artykule zostaną przedstawione wybrane wartości moralne związane $z$ wychowaniem w rodzinie polskiej, w ramach następujących szczegółowych zagadnień: rodzina jako wartość naczelna, cele ważne w wychowaniu dzieci, metody i techniki oddziaływania na

${ }^{13}$ J. Styk. Chłopi i wieś polska w perspektywie socjologicznej i historycznej. Lublin 1999 s. 117.

${ }^{14}$ H. Świda-Ziemba. Wartości egzystencjalne młodzieży lat dziewięćdziesiątych. Warszawa 1995 s. 287. 
dzieci oraz style wychowania w rodzinie. Kwestie te zostaną omówione w świetle wyników badań socjologicznych zrealizowanych w latach 1997-2000 w siedmiu miastach Polski (Jastrzębie Zdrój, Chełm, Rzeszów, Lublin, Gdańsk, Poniatowa, Ryki), w liceach ogólnokształcących i technikach, w klasach pierwszych i maturalnych. W sumie zebrano 2239 ankiet. Pracę tę wykonali studenci przygotowujący prace magisterskie w Katedrze Socjologii Moralności KUL. W końcowym raporcie z przeprowadzonych badań socjologicznych zostanie zamieszczona pełna lista uczestników.

W całej zbiorowości młodzieży było $47,2 \%$ mężczyzn i $52,8 \%$ kobiet; $52,0 \%$ - młodzież z liceów ogólnokształcących i 48,0\% - z techników i liceów zawodowych; 52,3\% - uczniowie klas pierwszych, 47,7\% maturzyści; $27,5 \%$ - mieszkający na wsi, $14,5 \%$ - w miastach do 20 tys. mieszkańców, $11,0 \%$ - w miastach od 20 do 100 tys. mieszkańców, $46,1 \%$ - w miastach powyżej 100 tys. mieszkańców (0,9\% - brak odpowiedzi). Struktura wykształcenia ojców badanej młodzieży przedstawiała się następująco: wykształcenie podstawowe lub mniej niż podstawowe $-5,7 \%$, zasadnicze zawodowe $-30,5 \%$; średnie ogólnokształcące lub techniczne $-25,3 \%$, pomaturalne $-9,9 \%$, niepelne wyższe $5,3 \%$, wyższe $-19,7 \%$, nie udzielający odpowiedzi $-3,6 \%$. Wykształcenie matek było na nieco wyższym poziomie i kształtowało się odpowiednio: $5,7 \%, 17,7 \%, 29,8 \%, 16,5 \%, 7,9 \%, 20,5 \%, 1,8 \%$. Charakterystyczne jest to, że często rodzice posiadali podobne wykształcenie. W calej zbiorowości młodzieży $36,4 \%$ badanych określiło swoją rodzinę jako inteligencką, 46,7\% - jako robotniczą, 14,7\% - jako chłopską $(1,1 \%$ - inne określenia, $1,2 \%$ - brak odpowiedzi). Sytuację materialną swojej rodziny młodzież oceniała jako wyraźnie dobrą - 16,9\% badanych, dość dobrą - 39,9\%, przeciętną - 36,8\%, raczej złą - 5,0\%, zdecydowanie zła - $0,6 \%$ (brak odpowiedzi - $0,8 \%$ ). Sytuacja materialna badanych osób była więc dość zróżnicowana.

\section{Rodzina jako wartość naczelna}

Rodzina - jak można wnioskować z wielu badań socjologicznych i sondaży opinii publicznej - jest wartością nadrzędną, nie tylko nosicielem, ale i obrońcą cenionych wartości. W społeczeństwie polskim przypisuje się rodzinie ważną wartość i rangę priorytetową. Według sondażu OBOP z 1998 r., przeprowadzonego na reprezentatywnej próbie doro- 
slych Polaków w wieku od 15 lat wzwyż ,30\% badanych uważalo, że życie rodzinne ma coraz większe znaczenie, $42 \%$ - że miało i ma takie samo znaczenie, $22 \%$ - że ma coraz mniejsze znaczenie i $6 \%$ - to niezdecydowani. Opinie pozytywne wypowiadali częściej ci, którzy jeszcze nie zawarli związku małżeńskiego i żyjące już we własnych rodzinach niż osoby rozwiedzione lub będące w stanie wdowim ${ }^{15}$.

Uznawane przez Polaków wartości życiowe wydają się charakteryzować znaczną trwałością od wielu już lat. Akceptuje się przede wszystkim cele ze sfery afiliacyjno-stabilizacyjnej. Wyraźna jest tendencja do ujmowania życia codziennego w kategoriach małych struktur, tj. rodziny i kręgu przyjaciól. Według niektórych badań socjologicznych z końca XX wieku rodzina polska traci stopniowo swoją priorytetową pozycję i plasuje się na dalszych miejscach. Wzrasta ranga wartości materialnych, a także wartości związanych z pracą i wyksztalceniem. Mówi się o postępującej pragmatyzacji i ekonomizacji świadomości społecznej. Wzrastająca lub obniżająca się lokata pewnych wartości jest odbiciem trendów zachodzących w makrostrukturze społecznej. Wyraźnie tracą na znaczeniu takie wartości życiowe jak możliwość wpływania na sprawy publiczne, przynoszenie ludziom pożytku (wartości prospołeczne) i wartości religijne. Także rodzina staje się poniekąd „ofiarą" procesów modernizacji społecznej i związanej z nimi deinstytucjonalizacji.

W europejskich badaniach nad wartościami w latach 1999-2000 postawiono m.in. pytania o ważność pewnych kwestii związanych z życiem codziennym. W Polsce najwyższe notowania otrzymała rodzina. Uznało ją za wartość szczególną 91,8\% badanych i tylko 0,5\% - zakwestionowało jej ważność (praca odpowiednio: 78,0\% i 3,8\%; przyjaciele i znajomi: $27,4 \%$ i $14,0 \%$; czas wolny: $24,8 \%$ i $17,9 \%$; polityka: $6,9 \%$ i $69,5 \%$; religia: $44,7 \%$ i $16,1 \%$ ). W 32 krajach europejskich $84,4 \%$ badanych deklarowało uznanie dla wartości „rodzina" i tylko 2,4\% negowało jej wartość (wartość „religia” odpowiednio: 20,9\% i $49,4 \%)^{16}$. W świadomości mlodych ludzi rodzina traci jednak na znaczeniu jako wartośćc ${ }^{17}$.

\footnotetext{
${ }^{15}$ Malżeństwo i życie rodzinne w opinii Polaków. Komunikat z badań OBOP (luty, 1998). Warszawa 1998 s. 4.

${ }^{16}$ L. Halman. The European Values Study: A Third Wave. Source Book of the 1999/2000. European Values Study Surveys. Tilburg 2001 s. 6-12.

${ }^{17}$ A. Keppler-Seel, H. Knoblauch, jw. s. 63.
} 
Ma rację L. Dyczewski, gdy pisze: „Wbrew wielu publicystom, a także niektórym socjologom głoszącym, że instytucjonalny charakter małżeństwa i rodziny może się załamać lub już przeżywa się, empiryczne badania wykazały, że instytucjonalny charakter nie załamuje się. Pozostaje ona nadal instytucją nie tylko u nas, ale nawet w najbardziej uprzemysłowionych i zbiurokratyzowanych społeczeństwach. Znajduje w nich swoje miejsce i jak dawniej jest niezastąpiona dla rozwoju jednostki i cenna dla spoleczeństwa" ${ }^{\prime}$. W relacjonowanych badaniach pierwsza kwestia dotyczyła znaczenia przypisywanego rodzinie przez młodzież polską. Rodzina była oceniana w kontekście najważniejszych planów życiowych: kariera zawodowa, wolność i niezależność, partner życiowy. Czy rodzina traci rzeczywiście na znaczeniu, czy załamuje się „familiocentryzm” jako specyficzna cecha społeczeństwa polskiego? Czy też „zdecydowanie najczęściej badana młodzież chce rodziny, która zapewni spokój i poczucie bezpieczeństwa, a jej przyjacielska atmosfera pozwoli zapomnieć o kłopotach i troskach, które niesie bieżące życie"19. Uzyskane wyniki empiryczne prezentuje tabela 1.

Tab. 1. Znaczenie przypisywane rodzinie (dane w \%)

\begin{tabular}{|l|c|c|c|c|c|c|c|c|c|}
\hline $\begin{array}{l}\text { Kategorie } \\
\text { odpowiedzi }\end{array}$ & $\begin{array}{c}\text { Jastrzębie } \\
\text { Zdrój }\end{array}$ & Chełm & Rze- & Lublin & Gdańsk & Ponia- & Ryki & \multicolumn{2}{|c|}{ Razem } \\
szów
\end{tabular}

W latach dziewięćdziesiątych cele i dążenia życiowe młodzieży koncentrowały się wokól dwóch kwestii: udanego i szczęśliwego życia rodzinnego oraz ciekawej, zgodnej z zainteresowaniami pracy. W ostatnich kilku latach zyskuje na znaczeniu zgodna $z$ wykształceniem i zain-

${ }^{18}$ L. Dyczewski. Rodzina polska i kierunki jej przemian. Warszawa 1981 s. 19.

${ }^{12}$ A. Kaleta. Aspiracje egzystencjalne młodzieży miejskiej. „Studia Socjologiczne” 1987, nr 1 s. 179. 
teresowaniami praca zawodowa. W całej zbiorowości młodzieży szkolnej $31,8 \%$ badanych preferowało rodzinę, $19,8 \%$ - karierę zawodową, $16,4 \%$ - wolność i niezależność oraz 9,2\% - partnera życiowego. Ponad jedna piąta respondentów nie potrafiła zająć stanowiska w omawianej sprawie, co może świadczyć o tym, że sprawy związane z założeniem rodziny, a nawet karierą zawodową są jeszcze dla nich kwestią odległą. Z wyjątkiem młodzieży z Rzeszowa rodzina jako wartość zajęła w świadomości badanych pierwsze miejsce. Na ogół na drugim miejscu plasowała się kariera zawodowa ( $\mathrm{z}$ wyjątkiem Lublina i Ryk), na trzecim miejscu - wolność i niezależność oraz zawsze na czwartym miejscu - partner życiowy.

Ogólnie można by powiedzieć, że rodzina jako wartość naczelna jawi się w świadomości trzeciej części badanej młodzieży. Jest to jednak jakby wartość w „stawaniu się", dopiero jakby na horyzoncie doświadczeń dorastającej młodzieży. Prawie połowa badanej młodzieży szkolnej wskazuje na inne wartości jako najważniejsze dla jej planów życiowych $(45,4 \%)$. Być może w świadomości części badanych rodzina nie jest przeżywana jako wartość konfliktowa wobec innych wartości życia codziennego, a akcentowanie np. kariery zawodowej nie skreśla rodziny z planów życiowych młodzieży. Na rodzinę jako wartość priorytetową częściej wskazywały kobiety niż mężczyźni $(36,3 \%$ wobec $26,9 \%)$, uczniowie techników częściej niż liceów ogólnokształcących $(33,1 \%$ wobec $30,6 \%$ ), młodzież z klas pierwszych podobnie jak i z klas maturalnych $(31,7 \%$ wobec $32,0 \%)$, młodzież mieszkająca na wsi $(34,8 \%)$ nieco częściej niż w miastach do 100 tys. mieszkańców $(33,0 \%)$ i w wielkich miastach $(29,4 \%)$, osoby głęboko wierzące $(43,1 \%)$ częściej niż wierzące $(35,0 \%)$, niezdecydowane w sprawach wiary $(20,2 \%)$ i niewierzące $(12,1 \%)$, osoby bardzo regularnie praktykujące $(42,4 \%)$ częściej niż regularnie praktykujące $(33,3 \%)$, rzadko praktykujące $(26,9 \%)$ i niepraktykujące $(23,3 \%)$.

W świetle omówionych wskaźników empirycznych można wnosić, że rodzina pozostaje względnie zwartą wspólnotą życia codziennego, jednak tylko trzecia część młodych akceptuje rodzinę jako wartość bezwzględnie najwyższą wśród wartości życiowych. Zwłaszcza takie plany życiowe jak kariera zawodowa, czy zabezpieczenie sobie wolności i niezależności, mogą być traktowane jako konkurencyjne wartości w stosunku do rodziny. Rodzina stanowi dla młodzieży w dalszym ciągu oparcie emocjonalne i pozytywną grupę odniesienia. 


\section{Cele ważne w wychowaniu dzieci}

Socjologowie stwierdzają, że współcześnie mamy do czynienia $\mathrm{z}$ osłabieniem dokonującej się $\mathrm{w}$ polskich rodzinach transmisji wartości między pokoleniami. Struktury rodzinne przestały być „schronieniem" przed zakusami totalitarnego państwa, a próżnia społeczna pomiędzy rodziną a państwem wypełnia się szybko rosnącą liczbą organizacji, stowarzyszeń, wspólnot i grup spolecznych realizujących różnorodne funkcje socjalizacyjne. Zmieniający się kontekst społeczno-kulturowy prowadzi coraz wyraźniej do personalizacji i modernizacji indywidualnie kształtowanych planów życia młodego pokolenia $^{20}$. Dzieciństwo i młodość stanowią ważne okresy w życiu każdego czlowieka.

W procesie socjalizacyjno-wychowawczym B. Zięba wymienia następujące zadania rodziny: „1) przekazywanie i przyswajanie dziedzictwa kulturowego zarówno w zakresie kultury materialnej (przede wszystkim przekazywanie i przyswajanie umiejętności korzystania z wytworów kultury materialnej), jak i kultury duchowej; 2) przekazywanie i uczenie się języka ojczystego; 3) ustalanie, przekazywanie i przyswajanie systemu wartości, który wyznacza cele działania, aspiracje, zachowania, postawy; 4) ustalanie, przekazywanie i przyswajanie środków, za pomocą których uznawane wartości, cele można osiągnąć oraz dostarczanie motywacji do działań prowadzących do uznanych przez rodzinę celów i wartości; 5) ustalanie, przekazywanie i przyswajanie norm postępowania członków rodziny wskazujących na określony zakres zachowań obowiązujących, zgodnych z oczekiwaniami rodziny; 6) ustalanie, przekazywanie i przyswajanie wzorów zachowania wyznaczonych przez wartości, cele, środki, motywacje i normy obowiązujące $\mathrm{w}$ rodzinie oraz umiejętności pełnienia rodzinnych i pozarodzinnych ról społecznych; 7) ocena i kontrola zachowań członków rodziny pod względem ich zgodności z przyjętymi normami, wzorami zachowania i wzorami osobowymi oraz stosowanie sankcji (dodatnich i ujemnych) w zależności od stopnia zgodności zachowań $\mathrm{z}$ uznawanymi, akceptowanymi normami i wzorami"21.

${ }^{20} \mathrm{~B}$. W. Mach. Międzypokoleniowy przekaz wartości w warunkach zmiany systemowej. „Kultura i Społeczeństwo" 38: 1994 nr 4 s. 34.

${ }^{21}$ Podaję za: Z. Tyszka. System metodologiczny wieloaspektowej integralnej analizy życia rodzinnego. Poznań 2001 s. 81 . 
W przekazie międzypokoleniowym ważne są treści moralne, które uważa się niekiedy za priorytetowe w wychowaniu. Wśród tych treści szczególną rolę w tradycyjnej moralności odgrywały takie zasady i nakazy, jak: prawdomówność, gotowość pomagania innym, posłuszeństwo, religijność i wiele innych cech niezbędnych w postawie moralnej człowieka. Niektóre z tych nakazów i zasad tracą na znaczeniu we współczesnych społeczeństwach pluralistycznych. Nawet w środowiskach wiejskich zaczyna przeważać partnerski model w relacjach rodzice-dzieci, chociaż nie zawsze jest on realizowany w praktyce ${ }^{22}$. Do rzadkości należy jeszcze styl wychowania „wolny od wartości”. Rodzina utrzymuje wciąż ważne miejsce w procesie społecznego i moralnego wychowania dzieci i młodzieży, a poszukiwanie w niej intymności i osobowego dialogu może być reakcją na bezosobowość relacji międzyludzkich.

W dziedzinie wychowania obserwujemy odwrót od tradycyjnych wartości powinnościowych (obowiązek), jak świadomość porządku, posłuszeństwo, dyscyplina, oszczędność. Zostają one zepchnięte jakby na drugi plan przez cele indywidualne (samodzielność, wolność, kreatywność, uznawanie celów wlasnych, zdolność do krytyki). Jeżeli dawny styl wychowania niósł z sobą niebezpieczeństwo autorytaryzmu, to obecny styl wychowania stanowi jego krańcowe przeciwieństwo (wychowanie emancypacyjne). Część młodych ludzi nie akceptuje systemu wychowania w rodzinie generacyjnej, uznaje go za niezbyt właściwy i wart realizacji wobec własnych przyszłych dzieci² ${ }^{23}$ Przemiany wartości w wychowaniu można ująć w skrótowej formie jako przejście od wartości - obowiązku do wartości samorozwojowych lub jako ewolucję od wychowania do posłuszeństwa i podporządkowania do wychowania w duchu niezależności i autonomii ${ }^{24}$. Pierwszy typ wychowania sprzyjal postawom autorytarnym, zależnym i hamującym potencjał innowacyjności w spoleczeństwie, drugi typ ksztaltuje postawy aktywne, samodzielne, zindywidualizowane i gwarantujące umiejętność radzenia sobie w niecodziennych warunkach ${ }^{25}$.

\footnotetext{
${ }^{22} \mathrm{~K}$. Gutkowska. Wybrane problemy rodzin wiejskich w Polsce. Warszawa 2000 s. 60-61.

${ }^{23}$ E. Budzyńska. Obraz rodziny u katowickiej młodzieży. W: Rodzina wobec wartości. Socjologiczne studium rodzin wielkomiejskich na przykładzie Katowic. Red. E. Budzyńska, J. Burzyński, A. Niesporek, W. Świątkiewicz. Katowice 1999 s. 80.

${ }^{24} \mathrm{H}$. Klages. Wertdynamik. Über die Wandelbarkeit des Selbstverständlichen. Zürich 1988.

${ }^{25}$ K. H. Reuband. Aushandeln statt Gehorsam? Erziehungsziele und Erzichungspraktiken in den alten und neuen Bundesländern im Wandel. W: Familien. Eine interdisziplinäre Einführung. Hrsg. von L. Böhnisch, K. Lenz. München 1997 s. 129.
} 
W procesie wychowania ważną rolę spełnia przekaz norm moralnych, spełniających centralną rolę w systemie interakcji społecznych. „Normy moralne, wchodzące w skład wartościującego aspektu wspólnej kultury, są rdzeniem mechanizmu stabilizującego system społecznych interakcji. Co więcej, mechanizm ten stabilizuje nie tylko postawy, czyli emocjonalne znaczenia osób dla siebie nawzajem, lecz również kategoryzacje, czyli poznawcze określenia ważności spolecznej osób"26. W ankiecie zrealizowanej wśród młodzieży uczęszczającej do różnych szkół średnich przedstawiono listę 22 cech, spośród których badani mogli wybrać nie więcej niż pięć odpowiedzi wskazujących na ważne cele w wychowaniu dzieci. Określając cele i zalety najważniejsze w wychowaniu respondenci pośrednio ocenili to, co jest wartościowe dla nich samych. Wartości są tu pojmowane jako to, co jest cenne w świadomości ludzi lub powinno być cenne. Analiza wartości i cech charakteru, które należy przekazywać dzieciom, jest ważna dla prognozowania rozwoju całego społeczeństwa. Uzyskane dane empiryczne zawiera tabela 2.

Tab. 2. Cechy szczególnie ważne w wychowaniu (dane w \%)

\begin{tabular}{|l|c|c|c|c|c|c|c|c|c|}
\hline $\begin{array}{l}\text { Kategorie } \\
\text { odpowiedzi }\end{array}$ & $\begin{array}{c}\text { Jastrzębi } \\
\text { Zdrój }\end{array}$ & Chełm & $\begin{array}{l}\text { Rze- } \\
\text { szów }\end{array}$ & Lublin & Gdańsk & Ponia- & Ryki & \multicolumn{2}{|c|}{ Razem } \\
towa & & \multicolumn{2}{|c|}{ Liczba $\%$} \\
\hline Oszczędnóś́ & 12,3 & 15,2 & 11,4 & 9,9 & 11,4 & 13,1 & 19,3 & 280 & 12,5 \\
\hline Uczciwość & 70,6 & 69,3 & 66,7 & 64,3 & 68,6 & 77,0 & 64,3 & 1520 & 67,9 \\
\hline Sumienność & 14,5 & 10,4 & 10,2 & 10,5 & 14,8 & 16,0 & 16,4 & 290 & 13,0 \\
\hline Pracowitość & 31,1 & 45,9 & 37,8 & 36,4 & 34,8 & 41,8 & 46,2 & 855 & 38,2 \\
\hline Opanowanie & 22,4 & 19,0 & 22,4 & 25,2 & 25,6 & 20,2 & 25,2 & 528 & 23,6 \\
\hline Wytrwałość & 24,5 & 18,2 & 30,1 & 23,5 & 27,0 & 21,6 & 20,2 & 540 & 24,1 \\
\hline Posłuszeństwo & 21,9 & 23,8 & 20,3 & 21,1 & 16,0 & 20,7 & 21,8 & 454 & 20,3 \\
\hline $\begin{array}{l}\text { Szacunek dla } \\
\text { siebie }\end{array}$ & 30,3 & 28,6 & 25,6 & 33,4 & 35,0 & 23,9 & 29,0 & 688 & 30,7 \\
\hline Cierpliwość & 24,6 & 21,2 & 30,5 & 28,1 & 27,6 & 26,8 & 28,6 & 607 & 21,4 \\
\hline Lojalnośćc & 7,9 & 6,5 & 9,8 & 12,5 & 9,8 & 13,6 & 12,6 & 238 & 10,6 \\
\hline $\begin{array}{l}\text { Dobre } \\
\text { obyczaje }\end{array}$ & 16,2 & 13,0 & 15,9 & 13,0 & 14,4 & 11,3 & 11,8 & 306 & 13,7 \\
\hline Własnó́ć & 27,2 & 28,1 & 23,6 & 24,7 & 21,0 & 21,6 & 22,3 & 533 & 23,8 \\
\hline Tolerancja & 33,8 & 29,9 & 38,2 & 34,1 & 37,2 & 30,0 & 25,6 & 750 & 33,5 \\
\hline
\end{tabular}

${ }^{26}$ T. Parsons. Struktura społeczna a osobowość. Tt. M. Tabin. Warszawa 1969 s. 47. 


\begin{tabular}{|l|c|c|c|c|c|c|c|c|c|}
\hline $\begin{array}{l}\text { Kategorie } \\
\text { odpowiedzi }\end{array}$ & $\begin{array}{c}\text { Jastrzębie } \\
\text { Zdrój }\end{array}$ & Chełm & $\begin{array}{l}\text { Rze- } \\
\text { szów }\end{array}$ & Lublin & Gdańsk & Ponia- & \multicolumn{2}{|c|}{ Ryki } & \multicolumn{2}{|c|}{ Razem } \\
towa & Liczba $\%$ \\
\hline $\begin{array}{l}\text { Wiara } \\
\text { religijna }\end{array}$ & 27,2 & 32,0 & 27,6 & 36,7 & 23,0 & 37,1 & 32,8 & 690 & 30,8 \\
\hline $\begin{array}{l}\text { Odpowie- } \\
\text { dzialność }\end{array}$ & 40,4 & 35,1 & 45,5 & 41,3 & 43,4 & 43,2 & 40,8 & 932 & 41,6 \\
\hline $\begin{array}{l}\text { Bezintere- } \\
\text { sowność }\end{array}$ & 7,5 & 7,8 & 8,9 & 8,2 & 8,0 & 6,6 & 6,3 & 174 & 7,8 \\
\hline Odwaga & 10,5 & 10,4 & 11,0 & 9,8 & 9,6 & 13,1 & 8,8 & 229 & 10,2 \\
\hline $\begin{array}{l}\text { Samo- } \\
\text { dzielność }\end{array}$ & 27,6 & 37,7 & 27,2 & 26,1 & 31,0 & 25,8 & 28,6 & 647 & 28,9 \\
\hline $\begin{array}{l}\text { Prawdo- } \\
\text { mówność }\end{array}$ & 40,8 & 35,5 & 40,7 & 37,6 & 32,8 & 33,8 & 31,1 & 804 & 35,9 \\
\hline $\begin{array}{l}\text { Systema- } \\
\text { tyczność }\end{array}$ & 9,6 & 5,6 & 6,1 & 8,4 & 7,8 & 6,6 & 8,4 & 172 & 7,7 \\
\hline Punktualnośćc & 7,9 & 4,3 & 6,1 & 5,1 & 6,8 & 6,1 & 5,0 & 132 & 5,9 \\
\hline Krytyczność & 2,2 & 4,8 & 4,9 & 5,7 & 4,0 & 6,1 & 4,2 & 104 & 4,6 \\
\hline Inne & 0,9 & 0,9 & 1,2 & 1,4 & 2,6 & - & - & 28 & 1,3 \\
\hline Brak danych & - & 0,4 & - & 1,2 & 0,4 & - & - & 10 & 0,4 \\
\hline
\end{tabular}

Uwaga: Dane nie sumują się do $100,0 \%$, ponieważ respondenci mogli wybierać kilka odpowiedzi.

We wszystkich badanych zbiorowościach na pierwszym miejscu pod względem częstotliwości wyborów cech i zalet ważnych w wychowaniu dzieci znalazła się uczciwość, a następnie odpowiedzialność, pracowitość, prawdomówność, tolerancja, wiara religijna i szacunek dla samego siebie. Granicy 30\% nie przekroczyly: samodzielność, cierpliwość, wytrwałość, poszanowanie cudzej własności, opanowanie, posłuszeństwo. Poniżej $20 \%$ aprobaty uzyskały cechy: dobre obyczaje, sumienność, oszczędność, lojalność, odwaga, bezinteresowność, systematyczność, punktualność i krytyczność wobec autorytetów.

Warto porównać wybory celów i zalet ważnych w wychowaniu dokonane przez młodzież szkolną $\mathrm{z}$ wyborami dokonanymi przez dorosłych. W europejskich badaniach nad wartościami w 1999 r. Polacy uważali następujące cechy charakteru ważne w wychowaniu dzieci: pracowitość - 85,3\%, odpowiedzialność - 72,7\%, wyobraźnia - 12,9\%, tolerancja i szacunek - 79,6\%, oszczędność - 38,1\%, determinacja, wytrwałość $-34,6 \%$, wiara religijna $-42,6 \%$, bezinteresowność - 
$12,1 \%$, posłuszeństwo - 32,3\% (w 32 krajach Europy odpowiednio: $53,1 \%, 75,2 \%, 19,6 \%, 72,9 \%, 38,3 \%, 38,1 \%, 22,4 \%, 28,6 \%, 30,0 \%)^{27}$. Jakkolwiek listy cech nie są w pełni porównywalne, to jednak dokonywane wybory wskazują na znaczne podobieństwo poglądów mlodzieży i ludzi doroslych. Uczciwość, pracowitość, odpowiedzialność i tolerancja są preferowane przez obydwie kategorie badanych osób.

Typ środowiska miejskiego, w którym uczy się badana młodzież, nie wprowadza wyraźnych różnic w wyborach cech (zalet) ważnych w wychowaniu dzieci, a istniejące różnice zamykają się w granicach $10 \%$. Szczególnie zbliżone są w poszczególnych środowiskach miejskich wybory wartości i celów uzyskujących niski poziom aprobaty, jak: oszczędność, dobre obyczaje, bezinteresowność, systematyczność i krytyczny stosunek do autorytetów. Kobiety częściej niż mężczyźni doceniały szacunek dla samego siebie (różnica 13,5\%), tolerancję (12,3\%), wiarę religijną $(6,7 \%)$ i prawdomówność $(10,2 \%)$, mężczyźni zaś częściej niż kobiety - oszczędność (różnica 9,8\%), sumienność $(9,4 \%)$ i pracowitość $(10,7 \%)$. W odniesieniu do pozostalych cech wskaźniki aprobaty były bardzo zbliżone, a różnice nie przekraczaly $5 \%$.

Młodzież ze szkól ogólnokształcących i technicznych dokonywała zbliżonych wyborów cech ważnych w wychowaniu, jedynie pierwsi częściej wskazywali na cierpliwość (różnia 8,3\%) i tolerancję $(11,6 \%$ ), drudzy zaś na oszczędność $(8,7 \%)$, pracowitość $(9,6 \%)$ i posłuszeństwo $(9,0 \%)$. Jeszcze bardziej zblizone były poglądy mlodzieży z klas pierwszych i maturalnych. Maturzyści nieco częściej preferowali tolerancję $(9,4 \%)$ i odpowiedzialność $(10,4 \%)$, „pierwszoklasiści” zaś posłuszeństwo $(10,8 \%)$ i prawdomówność $(6,0 \%)$. W miarę przechodzenia od kategorii młodzieży mieszkającej na wsi do kategorii młodzieży mieszkającej w wielkich miastach zmniejszała się aprobata trzech cech: pracowitości (od 45,9\% do 31,9\%), posłuszeństwa (od 25,0\% do $17,1 \%$ ) i wiary religijnej (od 39,2\% do 24,9\%), wzrastala zaś aprobata odpowiedzialności (od $36,7 \%$ do $45,0 \%$ ).

Religijność jako zmienna niezależna bardziej różnicuje wybory wartości ważnych $w$ wychowaniu niż cechy społeczno-demograficzne. Wraz z przejściem od głęboko wierzących do niewierzących zmniejszały się wskaźniki aprobaty takich cech, jak: uczciwości (od 73,4\% do $54,8 \%$ ), posłuszeństwa (od $25,4 \%$ do $13,4 \%$ ), wiary religijnej (od

${ }^{27}$ L. Halman. The European Values Study: a Third Wave. Source Book of the 1999/2000 European Values Study Surveys. Tilburg 2001 s. 146-150. 
$58,4 \%$ do $3,8 \%$ ), prawdomówności (od $38,8 \%$ do $31,2 \%$ ), wzrastaly zaś - opanowania (od 19,6\% do 34,4\%), wytrwałości (od 20,8\% do $29,9 \%$ ), szacunku dla samego siebie (od 20,6\% do $38,2 \%$ ), tolerancji (od 27,8\% do 40,8\%), odpowiedzialności (od 31,2\% do 49,0\%), samodzielności (od 19,9\% do 43,3\%). W ten sam sposób różnicowała wybory wartości ważnych w wychowaniu dzieci zmienna niezależna „praktyki religijne”. Osoby związane z religią bardziej akcentują te cechy, które wynikają bezpośrednio lub pośrednio z pedagogiki chrześcijańskiej, osoby o rozluźnionych związkach $z$ religią częściej wskazują na cechy ogólnoludzkie mające znaczenie wychowawcze niezależnie od religii.

Trudno jest określić, czy preferowane wartości ważne w wychowaniu ukladają się w pewien system, czy spójną hierarchię wartości. Próbujemy bliżej je określić poprzez jednorazowe wybory cech dokonywane przez badanych. Metoda przymusowego wyboru jednej wartości redukuje automatycznie szanse wyboru jakiejś innej wartości. Częstotliwość wyborów cech najważniejszych $w$ wychowaniu dzieci przedstawia się następująco: uczciwość - $26,0 \%$, odpowiedzialność - $11,5 \%$, szacunek dla samego siebie $-9,8 \%$, tolerancja $-7,8 \%$, wiara religijna $-7,3 \%$, prawdomówność $6,0 \%$, samodzielność $-4,7 \%$, cierpliwość $-4,2 \%$, pracowitość $-3,2 \%$, wytrwałość $-3,1 \%$, posłuszeństwo $-2,1 \%$, poszanowanie cudzej własności - 1,5\%, opanowanie - 1,1\%, sumienność - 1,1\%, lojalność - $1,0 \%$. Pozostałe cechy zostały zaakceptowane przez mniej niż $1,0 \%$ badanych.

Lista wartości zaakceptowanych jako najważniejsze wskazuje na ogromny rozrzut opinii co do znaczenia poszczególnych wartości. Pojawiają się wszystkie możliwe wybory, od wartości najwyżej do najmniej cenionych. Wśród wartości uznanych za priorytetowe pierwsze miejsce przypada uczciwości, chociaż nie w tak zdecydowany sposób jak w wyborach wielokrotnych. Blisko co dziesiąty badany preferuje odpowiedzialność, szacunek dla samego siebie, tolerancję i wiarę religijną. Wybory wartości najważniejszych w wychowaniu dzieci są zbliżone w poszczególnych miastach.

Wydaje się, że w latach dziewięćdziesiątych wzrosła aprobata takich wartości ważnych w wychowaniu, jak: uczciwość, szacunek dla samego siebie, pracowitość, tolerancja, odpowiedzialność, samodzielność i prawdomówność, zmniejszyła się zaś akceptacja wartości „wiara religijna” i „posłuszeństwo”. Podział preferowanych cech na dwie kategorie: zalety zorientowane na własną doskonałość i na własne ,ja" oraz zalety zorientowane na środowisko społeczne, wskazuje, że zalety odnoszące się do własnej osoby są wskazywane częściej niż zalety skierowane ku szerszym 
obszarom życia społecznego. Takie cechy jak lojalność, dobre obyczaje, poszanowanie cudzej wlasności są wybierane stosunkowo rzadko. Jedynie tolerancja jako cecha społeczna uzyskała wysoki poziom aprobaty. Badana młodzież częściej wybierała wartości osobowe ważne dla wychowania dzieci niż wartości skierowane na życie społeczne (wartości prospoleczne $)^{28}$. Być może w przyszlości rodzice będą bardziej dla dzieci przyjaciólmi niz autorytetami, osobami wspólnie z dziećmi podejmującymi decyzje dotyczące rodziny, bardziej skłonni do kompromisu i w wielu kwestiach dostosowujący się do potrzeb i poglądów dzieci² ${ }^{29}$.

\section{Metody i techniki oddziaływania na dzieci}

„Każde społeczeństwo określa, co dobre, a co zle, co ładne, a co brzydkie, co zacne, a co wstydliwe, co przyjemne, a co nieprzyjemne, oraz - by się posłużyć językiem bohaterstwa - dla czego warto żyć, a jeśli trzeba, to i umrzeć. Gdy się powiada dziecku, które źle postąpilo: „To paskudne, coś zrobil, wstydu nie masz!» - wpaja się mu wartość i normę przyjęte w jego społeczeństwie i przyzwyczaja się je do szanowania tych obyczajów - nie mogąc mu za bardzo przedstawić w tej mierze innego uzasadnienia prócz oczywistości. Każdy winien «czuć», co jest dobre, co zle" ${ }^{30}$. Te funkcje uczenia uczestnictwa w przekonaniach i postawach zbiorowych, podzielania wartości i norm uznawanych przez grupy, wypełniania ról społecznych, dziecko przyswaja sobie w rodzinie.

Wychowanie dzieci i młodzieży należy do podstawowych funkcji rodziny i jest szczególnie ważne we wczesnym dzieciństwie ze względu na istniejący mechanizm identyfikacji dziecka $z$ rodzicami, a także w okresie późniejszym ze względu na ważność świadectwa życia rodziców na miarę prawdziwie ludzką. W rodzinie dziecko uzyskuje we właściwy sposób poczucie własnej tożsamości, rodzina jest środowiskiem odpowiadającym naturalnej godności i powolaniu osoby ludzkiej. Więzi rodzinne

\footnotetext{
${ }^{28}$ W zbiorowości maturzystów z Warmii i Mazur najwyższą ocenę wśród zalet ważnych w wychowaniu moralnym uzyskała uczciwość $(77,3 \%)$ i szacunek dla rodziców $(73,6 \%)$, a następnie odpowiedzialność, samodzielność, tolerancja, pracowitość, pomoc innym, wiara religijna, posłuszeństwo i szacunek dla swojej godności (od 61,5\% do 41,2\%). M. Tunkiewicz. Małżeństwo i rodzina w świadomości młodzieży. Aspekt teologiczno-pastoralny. Olsztyn 2000 s. 101-102.

${ }^{29}$ Y. Schütze. Jugend und Familie. W: Handbuch der Jugendforschung. Hrsg. von H. H. Krüger. Opladen 1993 s. 345.

${ }^{30}$ H. Mendras. Elementy socjologii. T1. A. Biernacki. Wroclaw 1997 s. 80-81.
} 
są pierwszym czynnikiem przygotowującym do społecznych form solidarności i społecznego zaufania. Rodzice poprzez swoją działalność celową i spontaniczną rozwijają osobowość dziecka, określają wzorce zaspokajania potrzeb fizycznych i duchowych, w konsekwencji wyznaczają zakres i charakter internalizowanych wartości i norm. Zarówno w życiu rodzinnym, jak i w szerszych środowiskach społecznych, młodzież polska wyraża pragnienie realizacji dwóch nie w pełni koherentnych wartości: indywidualizmu i tolerancji oraz wspólnoty i więzi z innymis ${ }^{31}$.

„W dzisiejszej rodzinie występuje ogromne skoncentrowanie wysiłków rodziców na dziecku. Jest ono centrum ich trosk. Jego opiece i kontaktom z nim poświęcają wiele czasu, co daje dziecku ciąglą okazję do przeżywania swojej wartości i godności. Dziecko czuje, że jest coś warte, skoro rodzice tak o nie dbają"32. Troska o dziecko wydaje się priorytetową w rodzinach polskich. Pod koniec lat siedemdziesiątych ubieglego wieku S. Nowak pisał, że w Polsce „obszary ściśle osobistych standardów respondenta i standardów postrzeganych w kontekście jego rodziny są tak ze sobą powiązane, że z pewnego punktu widzenia rodzina może być uważana za rodzaj «rozszerzonej» osobowości jednostki. Jest to w naszym kraju prawdą dla wszystkich grup społecznych i wszystkich pokoleń. W związku z tym ogromna większość kryteriów i standardów, tj. pragnień i oczekiwań, a w konsekwencji większość wartościujących sądów ludzi skupia się na ich osobistym życiu, a także na życiu ich rodziny"33.

Od atmosfery domu rodzinnego zależy, czy stanowi on oparcie dla dzieci w trudnym dla nich wieku dojrzewania emocjonalnego, społecznego i moralnego, czy też jest źródłem dodatkowych napięć i konfliktów. „Stopień zadowolenia młodzieży ze swej sytuacji w rodzinie jest bardzo istotnie zależny właśnie od poczucia zrozumienia przez rodziców oraz od wymagań, jakie stawiają oni swym dzieciom. Oczywiście młodzież obdarza znacznie większą aprobatą swoje rodziny wówczas, gdy odnosi wrażenie, że jest zrozumiana przez rodziców oraz, że rodzice nie stawiają jej zbyt wygórowanych wymagań" ${ }^{\prime 34}$. Takie cechy jak zainteresowanie się dzieckiem, partnerskie uczestniczenie w jego sprawach, wsparcie i miłość rodziców, odgrywają ważną rolę w procesie wychowania.

\footnotetext{
${ }^{31}$ Ta dzisiejsza młodzież. Z profesor Hanną Świdą-Ziembą rozmawia Grzegorz Sieczkowski. „Gazeta Wyborcza. Magazyn Gazety” 1998 nr 46 s. 13.

${ }^{32}$ L. Dyczewski. Rodzina, społeczeństwo, państwo. Lublin 1994 s. 43.

${ }^{33}$ S. Nowak. System wartości społeczeństwa polskiego. „Studia Socjologiczne” 1979 nr 4 s. 156.

${ }^{34}$ Dzieci i młodzież o sobie. Ocena rodziny i szkoły. Sprawy ważne aktualnie i dążenia na przyszłość. Komunikat z badań OBOP (luty, 1998). Warszawa 1998 s. 9.
} 
Jak badana młodzież szkół średnich ocenia metody i techniki w wychowaniu rodzinnym? Czy akcentuje bardziej rygorystyczne czy lagodne sposoby oddzialywania na młode pokolenie? Jakie w ogóle uznaje środki nakłaniania jednostek do podzielania wartości, norm i wzorów zachowań uznawanych przez rodzinę? Respondenci odpowiadali na następujące pytanie: „Które z tych wartości uważasz za najważniejsze we właściwym wychowaniu młodego pokolenia?
A - przyklad osobisty rodziców
B - ścisły nadzór i kontrolę
C - zrozumienie przez rodziców problemów i kłopotów młodzieży
D - surowe kary w przypadku przewinień
E-rozmowy i przekonywanie
F - uchronienie od niewłaściwego towarzystwa
$\mathrm{G}$ - wyrozumiałość i tolerancja
$\mathrm{H}$ - okazywanie serdeczności
I - pozostawienie dużej samodzielności
$\mathrm{J}$ - konsekwencja w postępowaniu rodziców wobec dzieci
$\mathrm{K}$-inne (jakie?)".

Tab. 3. Metody i techniki ważne w wychowaniu młodego pokolenia (dane w \%)

\begin{tabular}{|l|c|c|c|c|c|c|c|c|c|}
\hline $\begin{array}{l}\text { Kategorie } \\
\text { odpowiedzi }\end{array}$ & $\begin{array}{c}\text { Jastrzębie } \\
\text { Zdrój }\end{array}$ & Chełm & $\begin{array}{l}\text { Rze- } \\
\text { szów }\end{array}$ & Lublin & Gdańsk & $\begin{array}{c}\text { Ponia- } \\
\text { towa }\end{array}$ & \multicolumn{2}{|c|}{ Ryki } & \multicolumn{2}{|c|}{ Razem } \\
Liczba $\%$
\end{tabular}

Uwaga: Dane nie sumują się do 100,0, ponieważ badani mogli wybierać po kilka odpowiedzi. 
We wszystkich środowiskach młodzieżowych najwięcej badanych uznało zrozumienie przez rodziców kłopotów i problemów młodzieży za najważniejszą wartość we właściwym wychowaniu młodego pokolenia, na drugim lub trzecim miejscu - osobisty przykład rodziców, wyrozumiałość i tolerancję. Na dalszych miejscach były aprobowane wartości: rozmowy i przekonywanie, okazywanie serdeczności, konsekwencja w postępowaniu, uchronienie od niewłaściwego towarzystwa i pozostawienie dużej samodzielności. Zupełnie marginesowo wybierano dwie wartości związane z „twardymi” metodami wychowania: ścisły nadzór i kontrola oraz surowe kary w przypadku przewinieñ ${ }^{35}$. Młodzież szkolna $\mathrm{z}$ różnych ośrodków miejskich prezentowała zbliżone poglądy na temat właściwych wartości w wychowaniu młodego pokolenia. Jeżeli nawet wybory poszczególnych wartości różnily się pod względem częstotliwości, to ranga im przypisywana była podobna, przesunięcia rangowe dotyczyły co najwyżej jednego miejsca.

Zbliżone wyniki empiryczne uzyskano w innych środowiskach młodzieżowych. Młodzież z klas trzecich liceów ogólnokształcących w Lublinie w 1997 r. spośród priorytetów wychowawczych w rodzinie najczęściej wskazywała na osobisty przykład rodziców (70,9\% badanych), wyrozumialość i tolerancję $(66,8 \%)$, rozmowę i przekonywanie $(44,9 \%)$ oraz okazywanie serdeczności $(43,2 \%)$. Znacznie rzadziej wymieniano: pozostawienie samodzielności $(29,1 \%)$ i uchronienie od niewłaściwego towarzystwa $(20,8 \%)$ oraz marginesowo: surowe kary w przypadku przewinień $(2,5 \%)$ oraz ścisły nadzór i kontrolę $(1,1 \%)^{36}$.

Wśród maturzystów w Kędzierzynie-Koźlu w 1998 r. respondenci wskazywali na następujące najważniejsze wartości w wychowaniu młodego pokolenia: osobisty przykład rodziców - 69,57\%, ścisły nadzór i kontrola $-5,25 \%$, zrozumienie przez rodziców problemów i kłopotów młodziezy - 83,21\%, surowe kary w przypadku przewinień $5,10 \%$, rozmowy i przekonywanie $-56,67 \%$, uchronienie od niewłaściwego towarzystwa - 42,88\%, wyrozumiałość i tolerancja - 73,16\%,

\footnotetext{
${ }^{35}$ Według sondażu Instytutu Studiów Społecznych w Warszawie z 1993 r. 16,2\% badanych dorostych Polaków zdecydowanie zgodzilo się z twierdzeniem, że czasami jest konieczne, by porządnym „laniem” przywołać dziecko do porządku, 37,6\% - zgodziło się, 30,2\% - nie zgodziło się, $13,4 \%$-zdecydowanie nie zgodziło się i $2,5 \%$ - nie miało wyraźnego zdania na ten temat. Polski Generalny Sondaż Spoleczny: Struktura skumulowwanych danych 1992-1994. Warszawa 1994 s. 145.

${ }^{36} \mathrm{P}$. Brożek. Tradycja religijna w środowisku pluralistycznym. Studium socjologiczne. Lublin 2000 s. 37.
} 
okazywanie serdeczności - 57,42\%, pozostawienie dużej samodzielności - 21,59\% i konsekwencja w postępowaniu rodziców wobec dzieci $46,93 \%$ (brak odpowiedzi $-0,9 \%)^{37}$.

Cechy demograficzne i społeczne nieznacznie różnicowały preferowane metody i techniki oddziaływania rodziców na dzieci. Kobiety częściej niż mężczyźni akcentowały zrozumienie przez rodziców problemów młodzieży (różnica 14,7\%), wyrozumiałość i tolerancję (14,6\%), okazywanie serdeczności $(11,8 \%)$, mężczyźni nieco częściej - ścisły nadzór i kontrolę (różnica 5,6\%). Młodzież z liceów ogólnokształcących częściej wymieniała wyrozumiałość i tolerancję (różnica 8,4\%) oraz konsekwencję w postępowaniu rodziców $(9,1 \%)$, młodzież uczęszczająca do szkół technicznych - uchronienie od niewłaściwego towarzystwa $(6,4 \%)$. Maturzyści wskazywali częściej niż ,pierwszoklasiści” na osobisty przykład rodziców (różnica $9,9 \%$ ), zrozumienie problemów młodzieży $(5,7 \%)$, rozmowy i przekonywanie $(6,1 \%)$, wyrozumiałość i tolerancję $(11,5 \%)$, okazywanie serdeczności $(11,8 \%)$, konsekwencję w postępowaniu rodziców $(11,0 \%)$. Młodzież mieszkająca na wsi i w miastach do 100 tys. mieszkańców prezentowała bardzo zbliżone poglądy $\mathrm{w}$ omawianej sprawie, natomiast mieszkająca w wielkich miastach wyraźnie częściej preferowała „miękkie" metody oddziaływania na dzieci (różnica wskaźników w porównaniu z młodzieżą wiejską wahała się od 1,8\% do 12,6\%).

Deklarowana religijność wbrew przypuszczeniom nie różnicowała preferowanych metod wychowania moralnego w rodzinie. Głęboko wierzący i wierzący jedynie częściej wskazywali na osobisty przykład rodziców i uchronienie od niewłaściwego towarzystwa, natomiast niezdecydowani w sprawach wiary, obojętni i niewierzacy - pozostawienie dzieciom dużej samodzielności (różnice poniżej 10\%). Podobne różnice akceptacji metod i technik oddzialywania wychowawczego zaznaczyly się w różnych kategoriach osób praktykujących. Praktykujący regularnie nieco częściej niż praktykujący rzadko lub w ogóle niepraktykujący aprobowali osobisty przykład rodziców i ochronę dzieci przed złym towarzystwem, ci drudzy dużą samodzielność.

Analiza odpowiedzi badanej młodzieży na temat preferowanych przez nią najważniejszych metod i technik w wychowaniu młodego pokolenia wykazała, że zdecydowana większość opowiada się za „miękkimi" metodami oddzialywania na wychowanków, zwłaszcza takimi jak

${ }^{37}$ E. Nycz. Dorastanie w przestrzeni spoleczno-kulturowej miasta przemysłowego. Studium socjologiczno-pedagogiczne. Opole 2001 s. 248-249. 
zrozumienie problemów młodzieży, tolerancja i osobisty przyklad rodziców ${ }^{38}$. W świetle uznawanych wartości wychowawczych można twierdzić, że dorastające pokolenie mlodych Polaków będzie realizować we własnych rodzinach lagodny styl wychowania, daleki od rygoryzmu, dyscypliny i posłuszeństwa, styl wychowania ewoluujący w stronę wzajemnego zaufania, zrozumienia, partnerstwa i dobrego przykładu ze strony rodziców ${ }^{39}$. Można przypuszczać, że ten akceptowany przez większość młodzieży polskiej repertuar metod i technik oddzialywania rodziców na dzieci będzie sprzyjał przenoszeniu na dzieci wartości, norm i wzorów zachowań przyjętych przez rodziców. „Miękkie” metody oddziaływania na dzieci nieco częściej akceptowały kobiety, młodzież uczęszczająca do szkół ogólnokształcących, maturzyści i młodzież mieszkająca w wielkich miastach. Religijność badanych przejawiająca się $w$ wierzeniach i praktykach kultowych nie oddziaływała różnicująco na ich poglądy w omawianej sprawie.

Wychowanie dzieci jest mimo zmieniających się kontekstów społeczno-kulturowych niezbywalnym obowiązkiem i niepodważalnym prawem rodziców. Rodzina powinna pomagać młodym ludziom w przyswajaniu sobie wartości moralnych, tworząc warunki sprzyjające harmonijnemu rozwojowi wszystkich wymiarów ich osobowości - fizycznego i duchowego, kulturalnego i spolecznego. Państwo - zgodnie z zasadą pomocniczości - nie powinno ograniczać kompetencji rodziny w wypelnianiu jej egzystencjalnych celów życiowych, przede wszystkim zaś jej zadań wychowawczych. Idzie tu także o wypracowanie skutecznych i właściwych metod służenia pomocą rodzinie poprzez środki i odpowiednie struktury wspomagające. Jeżeli jednak słuszne są diagnozy badaczy środowisk młodzieżowych mówiące o anomii i pustce aksjonormatywnej ${ }^{40}$, a także o silnej potrzebie autonomii i prawie do

${ }^{38} \mathrm{Z}$ sondażu ogólnopolskiego wynika, że $35 \%$ badanych rodziców nigdy nie bilo swoich dzieci, $50 \%$ stosowało te kary bardzo rzadko, $13,2 \%$ - czasami oraz około $1,1 \%$ stosowato często kary cielesne wobec swoich dzieci. A. Rodziewicz. Przemiany ról małżeńskich i rodzicielskich we wspótczesnych rodzinach polskich. W: Rodzina polska w okresie kryzysu i ożywienia gospodarczego (1990-1995). Red. W. Rakowski. Warszawa 1997 s. 169.

${ }^{30}$ K. Ryczan. Wartości katolików a typ środowiska miejskiego. Lublin 1992 s. 215.

${ }^{40}$ Większość młodzieży polskiej w okresie wchodzenia w dojrzałość społeczną i moralną wykazuje orientacje hedonistyczne, przy zupełnym niemal niedostrzeganiu prawa jako regulatora zachowań. Oznacza to zablokowanie rozwoju moralnego na poziomie przedkonwencjonalnym i wczesno-konwencjonalnym, używając języka L. Kohlberga, a zatem na poziomie dzieciństwa moralnego. Z. Kwieciński. Tropy - șlady - próby. Studia i szkice z pedagogii pogranicza. Poznań-Olsztyn 2000 s. 94. 
wyboru, wówczas dobór odpowiednich metod i technik oddziaływania wychowawczego nabiera szczególnego znaczenia. Jak nie nadużywając władzy i autorytetu, nie narzucając bezdyskusyjnie rozwiązań, przekazać uniwersalne wartości kultury moralnej? Jak realizować dialogowy a nie autorytarny styl wychowania, mający charakter współdziałania bardziej niż dozoru, sprawdzania, czy lustracji?

\section{Style wychowania w rodzinie}

Socjologowie podkreślają wzrost procesów emancypacyjnych dzieci w rodzinie, poszerzanie się zakresu ich swobody i niezależności. „Relatywnie zmniejszyl się świadomy wplyw rodziców na dzieci, ale w znacznie mniejszej mierze uległy zmniejszeniu wpływy wewnątrzrodzinnej spontanicznej socjalizacji. Rodzina w dalszym ciągu silnie oddziałuje na dzieci, jakkolwiek nastąpiła w jej ramach indywidualizacja oddziaływań ze względu na zróżnicowanie się postaw życiowych matek i ojców oraz ich działań wychowawczych. Procesy te silniej zaznaczają

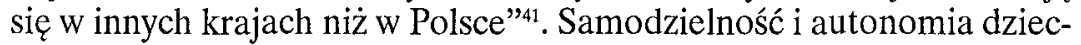
ka stają się jednym $\mathrm{z}$ ważnych celów wychowawczych. Wychowanie dzieci wymaga wielu osobistych wyrzeczeń, które z punktu widzenia „kosztów i zysków” mogą niejednokrotnie wydawać się irracjonalne. Prawdopodobnie rodzice zwalniają się normatywnie $z$ wychowywania dzieci, jeżeli hołdują zasadzie: „moje dziecko powinno w przyszłości zadecydować samo". Respektują w ten sposób nasilające się we wspólczesnym świecie tendencje do preferowania interesów i dążeń jednostkowych w stosunku do interesów i celów grupowych.

Rozwój komunikowania społecznego i bliskość kontaktów w rodzinie wplywają na rozwój poczucia bezpieczeństwa dziecka, akceptację siebie i innych ludzi, optymistyczne lub pesymistyczne nastawienie do życia, wyobrażenie o swoich planach i perspektywach na przyszłość. W procesie wychowania wyróżnia się dwa istotne komponenty: normatywny i emocjonalny. $Z$ kombinacji tych dwóch wymiarów wywodzą się cztery style wychowania: a) obojętny, gdy nie stawia się żadnych wymagań i nie stwarza się dzieciom oraz młodzieży emocjonalnego

\footnotetext{
${ }^{4} \mathrm{Z}$. Tyszka. Rodzina w świecie współczesnym - jej znaczenie dla jednostki i społeczeństwa. W: Pedagogika społeczna. Człowiek w zmieniającym się świecie. Red. T. Pilch, I. Leparczyk. Warszawa 1995 s. 149.
} 
oparcia w rodzinie; b) naiwny, gdy rezygnuje się z wymagań, chociaż rodzice usilują stworzyć serdeczną atmosferę w rodzinie i są zaangażowani emocjonalnie; c) paradoksalny, gdy rodzice stawiają, co prawda, wymagania, ale nie zabezpieczają emocjonalnego klimatu i uczuciowego wsparcia; d) dojrzały, gdy jasne wymagania łączą się z gotowością do rzeczywistego dyskursu $\mathrm{z}$ dziećmi i tworzenia osobowego klimatu w rodzinie ${ }^{42}$. Korzystną sytuację wychowawczą zarówno dla młodego pokolenia, jak i dla calej rodziny stwarza jedynie dojrzaly styl wychowania. Niemiecką propozycję badania stylów wychowania w rodzinie wykorzystano w ankiecie zrealizowanej wśród młodzieży szkolnej, która oceniała stosunek rodziców do niej samej (tab. 4).

Tab. 4. Style wychowania w rodzinie (dane w \%)

\begin{tabular}{|c|c|c|c|c|c|c|c|c|c|}
\hline $\begin{array}{l}\text { Style } \\
\text { wychowania }\end{array}$ & $\begin{array}{c}\text { Jastrzębie } \\
\text { Zdró́j } \\
\end{array}$ & Chełm & $\begin{array}{l}\text { Rze- } \\
\text { szów }\end{array}$ & Lublin & Gdańsk & $\begin{array}{c}\text { Ponia- } \\
\text { towa }\end{array}$ & Ryki & \multicolumn{2}{|c|}{$\begin{array}{c}\text { Razem } \\
\text { Liczba \% }\end{array}$} \\
\hline Obojętny & 5,3 & 9,5 & 8,9 & 9,1 & 6,4 & 8,9 & 13,4 & 192 & 8,6 \\
\hline Naiwny & 18,0 & 19,5 & 21,1 & 19,7 & 20,0 & 21,1 & 18,1 & 441 & 19,7 \\
\hline Paradoksalny & 24,6 & 26,8 & 20,7 & 19,4 & 17,4 & 21,6 & 15,5 & 452 & 20,2 \\
\hline Dojrzały & 51,3 & 43,3 & 47,6 & 50,1 & 54,4 & 47,4 & 52,5 & 1124 & 50,2 \\
\hline Brak zdania & - & - & - & 0,5 & 0,2 & - & - & 4 & 0,2 \\
\hline Brak danych & 0,9 & 0,9 & 1,6 & 1,2 & 1,6 & 0,9 & 0,4 & 26 & 1,2 \\
\hline Ogółem & 100,0 & 100,0 & 100,0 & 100,0 & 100,0 & 100,0 & 100,0 & 2239 & 100,0 \\
\hline
\end{tabular}

We wszystkich badanych zbiorowościach młodzieży szkolnej najczęściej wskazywano na dojrzały styl wychowania (od 43,3\% do 54,4\%), wyraźnie rzadziej na paradoksalny (od 15,5\% do 26,8\%) i naiwny (od 18,0 do $21,1 \%$ ) oraz najrzadziej na styl obojętny (od 5,3\% do 13,4\%). $\mathrm{O}$ dojrzałym stylu wychowania $\mathrm{w}$ rodzinach informowała nieco częściej młodzież z Gdańska, Ryk, Jastrzębia Zdroju i Lublina (powyżej $50 \%$ ). Pomiędzy zmienną niezależną "ośrodek szkolny” a poglądami na style wychowania $w$ rodzinie nie zaznacza się zależność statystyczna $(\mathrm{p}=0.048, \mathrm{C}=0.128)$.

Według uzyskanych danych empirycznych komponenty emocjonalne stylu wychowania w rodzinach polskich są uwzględniane w podobny

\footnotetext{
${ }^{42}$ G. Schmidtchen. Ethik und Protest. Moralbilder und Wertkonflikte junger Menschen. Opladen 1992 s. 97-101.
} 
sposób jak i komponenty normatywne (różnica 0,5\%), a naiwny styl wychowania jest stosowany podobnie często jak styl paradoksalny. Wydaje się powoli zanikać autokratyczny styl wychowania, rezygnuje się $z$ restrykcyjnych praktyk wychowawczych. Niemniej w co piątej rodzinie - według opinii badanej młodzieży - zaznacza się paradoksalny styl wychowania, akcentujący elementy jednostronnego podporządkowania dzieci rodzicom ${ }^{43}$.

Dziewczęta nieco częściej informowały o dojrzałym stylu wychowania w rodzinie $(52,8 \%$ wobec $47,3 \%)$, chłopcy nieco częściej o stylu paradoksalnym $(22,7 \%$ wobec $17,9 \%)$ i obojętnym $(9,4 \%$ wobec $7,9 \%)$. Różnice procentowe w wyborach stylów wychowania są niewielkie. Test chi-kwadrat $(\mathrm{p}=0.005)$ i współczynnik kontyngencji $(\mathrm{C}=0.082)$ wskazują na słabą zależność statystyczną. W rodzinach chłopców i dziewcząt kultywuje się zbliżone style wychowania. Uczniowie $z$ liceów ogólnokształcących w $54,4 \%$ wskazywali na dojrzały styl wychowania, w 20,2\% - na styl paradoksalny, w $17,6 \%$ - na styl naiwny i w 6,8\% - na styl obojętny (uczniowie $z$ techników i liceów zawodowych odpowiednio: $45,6 \%, 20,2 \%, 22,0 \%, 10,5 \%)$. Zależność obydwu zmiennych jest istotna ze statystycznego punktu widzenia $(p=0.001, C=0.104)$.

Uczniowie z klas pierwszych częściej niz z klas maturalnych deklarowali, że w ich rodzinach kultywuje się dojrzaly styl wychowania $(53,1 \%$ wobec $47,0 \%)$, rzadziej styl paradoksalny $(17,6 \%$ wobec $23,0 \%)$ i obojętny $(7,9 \%$ wobec $9,3 \%)$. Zależność pomiędzy klasą szkolną i stylami wychowania potwierdza test chi-kwadrat $(p=0.009$, $\mathrm{C}=0.078$ ). Osoby mieszkające na wsi w $49,6 \%$ informowały o dojrzalym stylu wychowania, w $18,2 \%$ - o paradoksalnym, w 21,6\% - o naiwnym i w $9,6 \%$ - o obojętnym (mieszkający w miastach do 100 tys. mieszkańców odpowiednio: $50,3 \%, 20,8 \%, 19,2 \%, 8,7 \%$; w wielkich miastach $-50,5 \%, 21,3 \%, 19,0 \%, 7,6 \%$ ). Pomiędzy pochodzeniem terytorialnym badanych a stylami wychowania $w$ rodzinie brak jest istotnej zależności statystycznej $(\mathrm{p}=0.518, \mathrm{C}=0.057)$.

Wśród osób glęboko wierzących $56,9 \%$ badanych deklarowało, że w ich rodzinach jest praktykowany dojrzały styl wychowania, 14,7\% -

${ }^{43}$ Według sondażu CBOS z 1998 r. co trzeci ankietowany był zdania, iż na ogół rodzice stawiają dzieciom nadmierne oczekiwania (32\%), tyle samo osób uważa, że nie stawiają żadnych wymagań (32\%) i że rodzice stawiając wymagania biorą pod uwagę możliwości sprostania im przez dziecko (31\%). M. Falkowska. Wychowanie dzieci w rodzinie i opieka nad nimi. Komunikat $z$ badań CBOS. BS/168/168/98. Warszawa 1998 s. 4. 
paradoksalny, $17,1 \%$ - naiwny i 8,6\% - obojętny (wśród obojętnych w sprawach wiary i niewierzących odpowiednio: $31,8 \%, 33,8 \%, 19,1 \%$, $14,6 \%$ ). W miarę przechodzenia od kategorii osób głęboko wierzących do kategorii osób niewierzących zmniejszał się odsetek ludzi mlodych informujących o dojrzałym stylu wychowania i wzrastal odsetek wskazujących na obojętny i paradoksalny styl wychowania. Test chi-kwadrat wskazywał na istotne statystycznie zależności pomiędzy analizowanymi zmiennymi $(\mathrm{p}=0.0001, \mathrm{C}=0.169)$. W podobnym kierunku oddziałuje zmienna niezależna „praktyki religijne”. W miarę przechodzenia od osób bardzo regularnie praktykujących do osób niepraktykujących zmniejszały się wskaźniki dojrzałego stylu wychowania: od 58,7\% do $39,8 \%$. Test chi-kwadrat potwierdza zależność statystyczną $(\mathrm{p}=0.001$, $\mathrm{C}=0.158$ ).

Dojrzały styl wychowania jako kultywowany w rodzinach respondentów jest nieco częściej wskazywany przez dziewczęta, uczniów z liceów ogólnokształcących, z klas pierwszych, mieszkających w wielkich miastach, głęboko wierzących i wierzących oraz regularnie praktykujących. Można przypuszczać, że dalsze zmiany będą zmierzać w kierunku większej łagodności sposobów wychowania, osłabienia stylu paradoksalnego i dojrzałego na rzecz obojętnego i naiwnego.

\section{Uwagi końcowe}

W szybko zmieniających się społeczeństwach współczesnych rodzina traci częściowo swoje funkcje wychowawcze, zmieniają się cele wychowania aprobowane przez rodziców. $\mathrm{O}$ ile dawniej rodzina koncentrowała się na przekazie określonych wartości i norm (często o charakterze religijnym), o tyle współcześnie przekazuje dzieciom wiedzę i umiejętności, jak zachowywać się w różnych sytuacjach życiowych w sposób skuteczny i elastyczny. Mniej skupia się na egzekwowaniu wzorców normatywnych, bardziej zaś na zaspokajaniu potrzeb emocjonalnych, osiąganych przez miłość, wzajemny szacunek, przywiązanie i zaufanie. W wielu rodzinach kształtują się „przyzwalające” postawy rodziców wobec dzieci. Członkowie rodziny mają swoje własne sprawy, odrębne tajemnice, którymi nie interesują się pozostali czlonkowie. Mało czasu spędza się w takich rodzinach na wspólnych rozmowach, dyskusjach czy zajęciach. Rodzice pozostawiają swoim dzieciom swobodę dysponowania czasem wolnym w sposób, jaki im najbardziej 
odpowiada. Spoleczeństwa wzrastającego dobrobytu stają się pod względem kulturowym coraz bardziej pluralistyczne, o różnych stylach życia i wychowania.

Nie wydaje się, by procesy przemian społeczno-gospodarczych i politycznych $w$ naszym kraju $w$ latach dziewięćdziesiątych wpłynęly w sposób zasadniczy na wybory aksjologiczne dokonywane w obrębie wartości ważnych w wychowaniu dzieci. Można jednak hipotetycznie założyć, że w okresie radykalnych zmian społecznych nieco bardziej docenia się takie cechy, jak: uczciwość, szacunek dla siebie, cierpliwość, tolerancję, odpowiedzialność, samodzielność i prawdomówność. Rzadziej zwraca się uwagę na religijność i posłuszeństwo. Wzrasta więc znaczenie tych cech, które sprzyjają nowemu kształtującemu się ladowi instytucjonalnemu w społeczeństwie, $\mathrm{z}$ akcentem na kreatywność i odniesienie sukcesów w życiu. Dokonująca się w świadomości moralnej dzieci i młodzieży reorientacja ku wartościom osobistym (samorozwojowym) wyciska swoje piętno na celach wychowania w rodzinie. Zmieniający się rozkład wartości ważnych w wychowaniu jest po części wynikiem przemian pokoleniowych, po części zaś reakcją na wplyw innych czynników.

Uznawane przez mlodzież wartości ważne w wychowaniu dzieci nie w pełni pokrywają się z tymi, które preferują rodzice, czy w ogóle pokolenie ludzi dorosłych ${ }^{44}$. Dla wielu jednak w dalszym ciągu styl wychowania $w$ rodzinie pochodzenia jest wzorem, jaki będzie realizować młodzież w swoim dorosłym życiu. Wydaje się, że w relacjach wzajemnych rodziców i dzieci jest jeszcze dużo pozytywnego, emocjonalnego klimatu. Na liście zalecanych metod wychowawczych niewielką popularnością cieszą się kary fizyczne. Za bardziej skuteczną metodę wychowawczą uważa się okazywanie życzliwości, tłumaczenie i prezentowanie pozytywnych wzorów. Jakkolwiek Polacy mają na ogół negatywny stosunek do kar fizycznych w wychowaniu dzieci, to jednak w praktyce latwo godzą się na różne formy przymusu wobec dzieci, a nawet je stosują. Młodzież wyraźnie odrzuca stosowanie ścisłej kontroli i kar w wychowaniu.

W społeczeństwie polskim rygoryzm i egzekwowanie posłuszeństwa przemieniają się powoli w postawy liberalne, a przynajmniej toleran-

\footnotetext{
${ }^{4}$ Wśród ludności wiejskiej uznano za cechy istotne w wychowaniu następujące wartości: poszanowanie rodziców, pracowitość, prawdomówność, posłuszeństwo, szacunek dla samego siebie i inne. K. Kutiak. Rodzinne wartości wychowawcze podkarpackiej wsi (na przykładzie badań rodzin Bukowska). Olsztyn 2000 s. 139.
} 
cyjne wobec dzieci. Poszerza się sfera samodzielności przyznawanej dzieciom, która jest uznawana za znaczącą cechę nowoczesności. Wychowanie polega m.in. i na tym, by prowadzić dziecko do samodzielnego i twórczego znajdowania właściwego miejsca w rodzinie i w społeczeństwie różnorodnych opcji. Samodzielność dziecka rodzice mogą kształtować w różny sposób i z różną intensywnością, jest ona związana z preferowanym przez rodziców systemem wychowania. Wydaje się, że współcześnie polska młodzież ma znacznie więcej autonomii i samodzielności niż 20-30 lat temu (ewolucja od zewnętrznego konformizmu do samosterowności $)^{45}$.

Pozytywne kontakty rodziców $z$ dziećmi wpływają w znacznym stopniu na skuteczność oddziaływań wychowawczych i socjalizacyjnych. Dokonująca się ewolucja poglądów młodzieży na temat wartości ważnych we wlaściwym wychowaniu młodego pokolenia znajduje swoje reperkusje we wzorach zachowań rodziców wobec dzieci. Od atmosfery domu rodzinnego i stosowanych w nim metod wychowawczych zależy, jak układają się relacje między rodzicami i dziećmi, czy dzieci znajdują w nim opiekę i oparcie.

Wysokie wartościowanie rodziny nie musi oznaczać tego, co E. Banfield nazywał "rodzinnością amoralną" (kierowanie się w działaniu wyłącznie interesem rodziny, niezależnie od zasad moralnych) ${ }^{46}$. Może jednak rodzina nabierać cech „wspólnoty ochronnej”, w której członkowie wybierają drogę życia ściślej określoną i bardziej wykonalną, nawet jeżeli w takich wspólnotach więzi grupowe są ważniejsze niż indywidualny rozwój ${ }^{47}$. Dom rodzinny jest źródłem poczucia bezpieczeństwa, gdzie można się schronić, a nawet oddzielić od zewnętrznego świata. Rodzina powinna być nadzieją na przyszłość, sama jest jednak wyraźnie zagrożona, dotknięta wewnętrznymi sprzecznościami i na ogól niedoceniana ${ }^{48}$.

Rozpadowi środowiska wychowawczego rodziny próbuje przeciwstawiać się Kościół katolicki i inne instytucje wychowania bezpośred-

${ }^{45}$ Przeciwnie, $z$ ankiet wynika, że młodsza generacja odznacza się wrażliwością na więcej problemów etycznych niż poprzednie pokolenia. Nie kojarzy jednak tych wartości z tradycją i nie zgadza się, by autorytety miały ustanawiać w tradycyjnej formie prawa dotyczące stylu życia. A. Giddens. Trzecia droga. Odnowa socjaldemokracji. Tt. H. Jankowska. Warszawa 1999 s. 37.

${ }^{46} \mathrm{H}$. Mendras, jw. s. 82.

${ }^{47}$ B. Mikolajewska. Ochronna wspólnota i tożsamość jednostki w ujściu Barriego Newmanna. W: B. Mikołajewska. Zjawisko wspólnoty (Wybór tekstów). New Haven 1999 s. 222-223.

${ }^{48}$ M. J. Szymański. Kryzys i zmiana. Studia nad przeobrażeniami edukacyjnymi w Polsce w latach dziewięćdziesiątych. Kraków 2001 s. 157-166. 
niego i pośredniego, podkreślając centralną rolę rodziny. W rodzinie dokonuje się bowiem przekaz wartości oraz integralna promocja, która oznacza wszechstronne wychowanie dzieci i młodzieży. Kościół wskazuje na stalą i pilną potrzebę odkrycia wartości rodziny tak, by była ona miejscem, gdzie panuje klimat pokoju i tolerancji, ułatwiający każdemu członkowi rodziny harmonijny rozwój osobowy i duchowy. Rodzina jest i pozostanie podstawową niezastąpioną wspólnotą wychowawczą, środowiskiem stwarzającym najlepsze warunki do przekazywania wartości pomagających jednostce w kształtowaniu własnej tożsamości, wartości istotnych dla rozwoju całego społeczeństwa.

\section{Moralische Erziehung in der Fanilie}

\section{Zusammenfassung}

Im vorliegenden Artikel werden ausgewählte moralische Werte im Zusammenhang mit der Erziehung in der polnischen Familie vorgestellt, und zwar im Rahmen folgender Detailfragen: Die Familie als höchster Wert, Wichtige Ziele in der Kindererziehung, Methoden und Techniken der Einwirkung auf die Kinder sowie Erziehungsstile in der Familie. Diese Fragen werden im Lichte der Ergebnisse soziologischer Untersuchungen behandelt, die in den Jahren 1997-2000 in sieben Städten Polens (Jastrzębie Zdrój, Chełm, Rzeszów, Lublin, Gdańsk, Poniatowa, Ryki) in allgemeinbildenenden Mittelschulen (Lyzeen) und technischen Fachschulen (erste und Abiturklasse) durchgeführt wurden. Von Studenten, die ihre Diplomarbeiten am Lehrstuhl für Soziologie der Moral der KUL vorbereiteten, wurden insgesamt 2239 Fragebögen ausgewertet. Die sozial-ökonomischen und politischen Wandlungsprozesse in Polen in den neunziger Jahren scheinen die axiologischen Wahlentscheidungen auf dem Gebiet der für die Kindererziehung wichtigen Werte nicht prinzipiell beeinflußt zu haben. Jedoch kann hypothetisch davon ausgegangen werden, daß in einer Zeit radikaler sozialer Wandlungen solche Eigenschaften wie Ehrlichkeit, Selbstachtung, Geduld, Toleranz, Verantwortlichkeit, Selbständigkeit und Wahrheitsliebe höher eingeschätzt werden, während auf Religiosität und Gehorsam seltener Nachdruck gelegt wird. Somit nimmt die Bedeutung derjenigen Merkmale zu, die die sich neu herausbildenende institutionelle Ordnung in der Gesellschaft begünstigen, mit besonderer Betonung der Kreativität und des Erfolgs im Leben. Die sich im moralischen Bewußtsein der Kinder und Jugendlichen vollziehende Umorientierung auf persönliche Werte (der eigenen Entwicklung) prägt auch die Erziehungsziele in der Familie. Die sich verändernde Verteilung der in der Erziehung wichtigen Werte bildet zum Teil das Ergebnis eines Generationswechsels, zum anderen eine Reaktion auf den Einfluß anderer Faktoren. 